\title{
SHORTENING DAYS AT THE HOMESTEAD
}

THE first fire since the summer is lit, and is smoking into the room:

The sun-rays thread it through, like woof-lines in a loom.

Sparrows spurt from the hedge, whom misgivings appal

That winter did not leave last year for ever, after all.

Like shock-headed urchins, spiny-haired,

Stand pollard willows, their twigs just bared.

Who is this coming with pondering pace, Black and ruddy, with white embossed, His eyes being black, and ruddy his face And the marge of his hair like morning frost?

It's the cider-maker, And appletree-shaker, And behind him on wheels, in readiness, His mill, and tubs, and vat, and press. 